\title{
Contributors
}

Lindon Barrett, Assistant Professor of English and Comparative Literature at the University of California, Irvine, is the author of essays published or forthcoming in Callaloo, Cultural Critique, SubStance, and in the anthology Teaching Theory to Undergraduates. He is currently writing a book on value, representation, and authority in relation to African American literature and culture.

JEROME BRUNER, Research Professor of Psychology at New York University and most recently Senior Research Fellow in Law there, has published numerous books, among them Acts of Meaning; In Search of Mind: Essays in Autobiography; and Actual Minds, Possible Worlds. He is currently working on Autobiography and the Construction of Self.

ROBERT FOlkenflik, Professor of English and Comparative Literature at the University of California, Irvine, is the author of Samuel Johnson, Biographer and other books. He has published numerous essays on autobiography, the eighteenth-century novel, and the artist as hero. He has held fellowships from the Guggenheim Foundation, the National Endowment for the Humanities, and other sources.

BAR B ARA D. METCALF, Professor of History at the University of California, Davis, was recently a fellow at the National Humanities Center. Her publications include Islamic Revival in British India; Moral Conduct and Authority: The Place of Adab in South Asian Islam; and Perfecting Women: Maulana Ashraf 'Ali Thanawi's Bihishti Zewar.

genaro M. PAdilla, Associate Professor of English at the University of California, Berkeley, has published numerous essays on Chicano literature and autobiography. His book History, Memory and the Struggles of Self-Representation: The Formation of Mexican American Autobiog- 
raphy will appear in the American Autobiography series of the University of Wisconsin Press in 1993.

RONALD paulson, Mayer Professor of the Humanities at The Johns Hopkins University, is the author of numerous books, including Hogarth: His Life, Art and Times; Representations of Revolution; and, most recently, Breaking and Remaking: Aesthetic Practice in England, I700I820. A three-volume revision of Hogarth is being published by Rutgers University Press. He is Senior Editor of English Literary History.

Linda H. PETERSON, Professor of English at Yale University, has published Victorian Autobiography: The Tradition of Self-Interpretation and a number of essays on women's autobiography that will appear in a forthcoming book.

ROGER J. PORTER, Professor of English at Reed College, is co-editor of The Voice Within and the author of numerous articles on autobiography. He is currently completing a book on that topic.

John STURrock, Consulting Editor with the London Review of Books and sometime Regents' Lecturer at the University of California, Los Angeles, has published a variety of books, including Structuralism; Paper Tigers: The Ideal Fictions of Borges; and The French Pyrenees. His Language of Autobiography will be published in 1993 by Cambridge University Press.

Julia watson, Associate Professor of Humanities at the University of Montana, writes on gender and the theory and practice of autobiography. She is co-editor with Sidonie Smith of De/Colonizing the Subject: The Politics of Gender in Women's Autobiography. Her essays include "Shadowed Presence: Women's Autobiography and the Other" (in Studies in Autobiography), and pieces on Montaigne, Rilke, and new German film. 


\section{THE CULTURE OF}

AUTOBIOGRAPHY 
